THURSDAY, JULY 7, 1887.

\section{PROFESSOR TYNDALL AND THE SCIENTIFIC MOVEMENT.}

T. $\mathrm{E}$ complimentary banquet to Prof. Tyndall, to which reference has more than once been made in these columns, is described in detail elsewhere. We cannot, however, allow an event of so much interest, and which is, we believe, unique in the history of science in this country, to pass without comment.

Many notable gatherings have taken place in Willis's Rooms, but we question if English science has ever been more completely represented than at the "Tyndall Dinner." The President of the Royal Society was in the chair. The seven Vice-Chairmen were Presidents of the most important scientific Societies. The tables were crowded with men whose names are known wherever Nature is studied.

No every-day motive would suffice to bring together such an assembly, and it is not every day that we have an opportunity of doing honour to a life-work such as that of Prof. Tyndall. Others will rank beside or above him as investigators, but in the promotion of the great scientific movement of the last fifty years he has played a part second to none. The English people are a determined but somewhat slow-witted race, and it has been no easy task to convince them that a new era-that of sciencewas dawning. They have been content to pride themselves on industrial successes due for the most part to isolated efforts of genius, which was hampered by unnecessary difficulties, and which cannot be produced at will. They were long in seeing, they do not yet fully see, that our industrial position can only be maintained if armies of well-equipped followers are ready to seize the ground which the leaders win.

There is, however, a still harder lesson to learn. The industrial application of a scientific principle-vitally important to the well-being of the people as that application may be-requires nevertheless a lower form of intelJectual energy than the discovery of the principle itself. The triumphs of applied science, of the physician, the engineer, the telegraphist, are readily "understanded of the people." The research laboratory, on the other hand, is open to few. The flash of genius which has wrung a fresh secret from Nature can only be fully appreciated by those who are intellectually competent to understand the difficulty and the success. And yet, if a widespread knowledge of science was to be, as it is, an essential condition of national well-being, it was absolutely necessary that the people should know something of, and be in some sort in sympathy with, the methods and conditions of scientific thought.

In supplying this need, Prof. Tyndall's greatest work has been done. Uniting scientific eminence of no ordinary kind with extraordinary gifts of exposition, he has, by his lectures and his books, brought the democracy into touch with scientific research. In dozens of lecture-rooms experiments devised by him are proving that a living science is a nobler instrument of education than a dead language. In hundreds of libraries his nervous English is convincing men of the VoL. XXXVI.-No. 923. value of a career like Faraday's, and teaching them to appreciate, if they cannot always in detail follow, the methods by which the victories of science are won. $\mathrm{He}$ has done perhaps more than any other living man to compel those who regard knowledge as valuable only in so far as it is immediately useful, to admit that the seed which is sown in the laboratory often produces the most abundant harvest in the workshop, and that a desire for knowledge is the mother of inventions which necessity could never have brought to the birth.

Such has been Prof. Tyndall's work ; and yet we venture to think that among those who met in Willis's Rooms a deeper feeling was aroused than admiration for an eminent worker and a useful career.

Many of the greatest masters both of the moral and intellectual life have sought the attainment of their highest ideals in a more or less complete withdrawal from society, and it may well be that some natures can best achieve in seclusion the concentration which a supreme effort demands.

But although the scientific movement of to-day may receive its highest inspirations from men who, like Darwin and Joule, have worked in self-imposed retirement, its distinguishing characteristic is that it is sweeping along with it all classes and all opinions. It is a new habit of thought in the light of which the foundations of our educational, industrial, and political systems are being reconsidered. It is a new and deliberate attempt to put into practice the belief that "the sovereignty of man lieth hid in knowledge, wherein many things are reserved which kings with their treasures cannot buy, nor with their force command; their spials and intelligencers can give no news of them; their seamen and discoverers cannot sail where they grow."

Thus it has come to pass that science has gathered round it a crowd of workers, engaged in very various tasks, but all of whom would be ready to admit that the cardinal principle of the movement in which they take part is the investigation of truth for truth's sake alone. They may be professors or manufacturers, soldiers or physicians. If only they are imbued with the desire to penetrate a little further into the mysteries which surround us, if only they are willing and able to add something to the sum of human knowledge, they are scientific men.

In part this army is organized. There is in England no Academy of Literature. The Academy of Arts, it is admitted, needs reform. The principal scientific Societies, however, with the Royal Society at their head, perform the duties of an Academyof Science to the general satisfaction. No human institution is perfect, but it may be fairly said that they set in their Transactions a high standard of scientific work, and that their judgment, whether of men or of investigations, is seldom challenged.

In spite of this advantage, neither the outside world nor scientific men themselves have as yet sufficiently realized that these Societies constitute a great guild of that learning which is the most powerful and the most characteristic influence of our age.

On an occasion such as the Tyndall Dinner this realization is quickened. The curious magnetic influence of numbers is felt. Minor differences disappear in the 
knowledge that all are workers in the same cause. Men become more vividly conscious that though students of Nature are excluded from the State recognition which is extended to the $\mathrm{Ch}$ urch, to medicine, and to the law, they too are members of a great profession. They realize that, though State rewards are given only to those who have applied their knowledge to some directly useful end, in a gathering of the profession of science the true leaders are those who have wrested the deepest secrets from Nature, careless whether they could be turned to gold or no.

A meeting held in great numbers and for a common purpose may have an influence which many an apparently more useful testimonial would lack. Prof. Tyndall has done service in the cause of science which merited the unique compliment he receivec. He would, we believe, be the first to rejoice if in the future the Tyndall Dinner was remembered not only as a tribute to his own work, but as marking the beginning of a period in which the ranks of science were drawn closer together, and in which the further organization of the investigation of Nature claimed and received the attention which its importance demands.

\section{THE GEOLOGY OF ENGLAND AND WALES.}

The Geology of England and Wales. With Notes on the Physical Features of the Country. By Horace B. Woodward, F.G.S. Second Edition. (London: Philip and Son, 1887.)

THE student of physical geology has at least two large English text-books, interesting, full, accurate, judicial, and written by masters of the science; but he who would build on this foundation a knowledge of historical and palæontological geology is in a hurder case, and finds either a meagre outline containing little but a few meaningless names of formations and fossil lists, or else an illdigested and formless mass of matter, derived from everywhere, but leading nowhere. Perhaps the time has not yet come when stratigraphy can be treated from the stand-point of inorganic evolution, so that fact may be joined to his fact and an organized whole result.

While, however, we wait for one who shall give us geology in the form of the inorganic and organic evolution of the globe, we must not omit to notice the labour of those whose "work is to record the facts from which the pleasanter deductions may be made." Mr. Woodward has done wisely in republishing by subscription and in an enlarged form his admirable book on the geology of England and Wales-a veritable mine of facts, well indexed and admirably supplied with references for the advanced reader, forming a base-line for further study and research, but complete in itself for the more elementary student and rendered interesting by the author's fresh style, by his capital and apt illustrations, and by his wonderful faculty of seizing upon the individuality of the rock group he is describing and skilfully tracing its variations from place to place. This new edition is improved by a larger and better map, undertaken by Mr. Goodchild, by more free use of sections, illustrations, and fossil lists, and by the employment of local names with tables of correlation.

The author works his way upwards from the lowest rocks, but combines a geographical with a chronological arrangement, and varies his method from system to system in order to adapt it better to the rocks under consideration. Just occasionally one meets with a slip in method, as in the case of the Rhætic rocks, where for no apparent reason he has reversed his usual order and treated the White Lias first. Where the mass of facts is unusually great and somewhat barren of interest, the author has introduced little helps and alleviations for which the student will be truly grateful,--the character of the hero of a system sketched in one graphic touch, the origin of the name of a system or a fossil, or the discussion of the origin of some bed of palæontological or economic value (vide pp. $24,47,84,266,670$ ).

It seems hard to criticise any points of detail in such well-intentioned and well-executed work, but the indication of a few lines for improvement will perhaps show better than anything else how little the author has left for others to suggest. First, with regard to the map. This is clearly engraved, and coloured with light but wellcontrasted tints; every name on it suggests some fact interesting from a geologist's point of view, and the effect of the whole is pleasing. There is no special colour for the Permian (not an unmixed advantage), and, oddly enough, the Yorkshire coal-field is left uncoloured; the boundary is engraved, however, and the student can easily fill in the colour for himself. A point has been gained in using a distinctive colour for beds below the Bala, but one lost in not using still another for the lowest Cambrians. The igneous rock colours should have been used less sparingly, and surely the Arenigs and Snowdon deserve a volcanic tint as much as the Borrowdales and the Cheviot rocks. We miss, too, the north of England dikes and the Whinsill.

The book opens with an introduction containing a little history, a little cosmogony, and a few definitions. The latter are hardly needed, and might have made room for the accounts of the geology of different lines of railway, which found a place in the first edition but have been crowded out of this. A few words on the Palæozoic group are followed by an account of the Archæan system, in which too little is said of the new class of work amongst these rocks institute 1 by Prof. Lapworth, while Prof. Bonney's papers on the Bangor area are almost passed over. The table on page 52 hardly makes it quite clear that the Harlech group of St. David's is divided into the Caerfai and Solva groups, of which the former constitutes the Annelidian of Lapworth, and the latter, together with the Menevian beds, the Paradoxidian. On page 58 we find the time-worn section across that part of the Longmynd which teaches nothing of the succession of the Longmynd rocks; this and several other sections should have been orientated. On page 6o the Hollybush sandstone is omitted from the table of Shropshire Cambrians, and awkwardly placed on page 65 , while the Shineton shales are correlated with the Dolgelly beds and Malvern black shales in the table, though afterwards correctly placed with the Dictyonema shales and Lower Tremadoc. A deceptive appearance of unconformity in sections on page 89 might easily have been removed, even if present in the original woodcut. It is good to see Mr. Lewis's name brought up with 